\title{
The Australian Journal of
}

\section{Rehabilitation Counselling}

cambridge.org/jrc
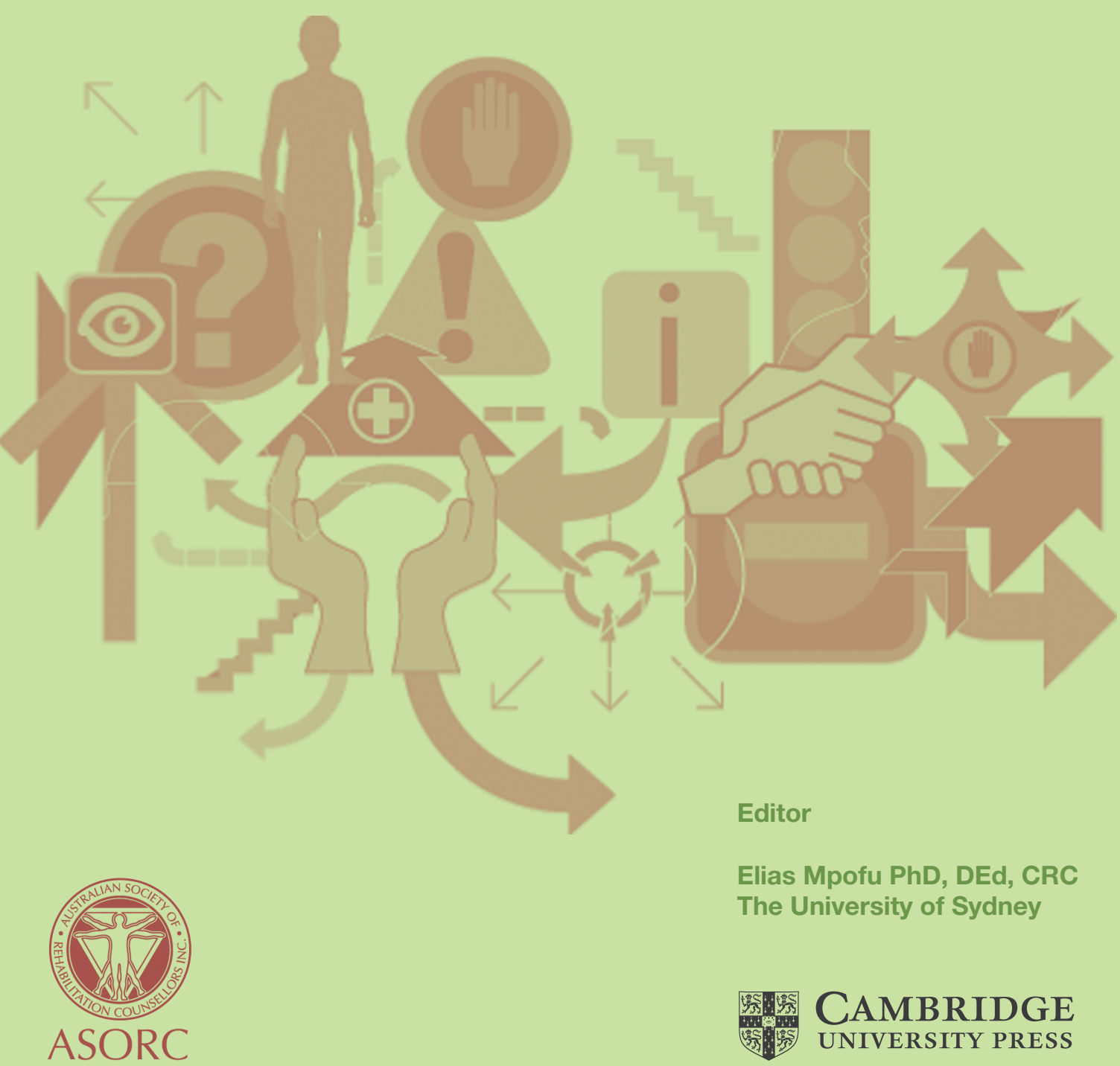

Elias Mpofu PhD, DEd, CRC The University of Sydney 


\section{The Australian Journal of}

\section{Rehabilitation Counselling}

\section{EDITORIAL BOARD}

\section{Editor}

Elias Mpofu, PhD, DEd, CRC

The University of North Texas, TX, USA

Associate Editors

Gregory C. Murphy, PhD

La Trobe University, Australia

Fong Chan, PhD, CRC

University of Wisconsin-Madison, USA

Consulting Editors

Timothy N. Tansey, PhD

University of Wisconsin-Madison, USA

Jessica Brooks, PhD

University of North Texas, USA

Beatrix Algurén, PhD

Jönköping University, Sweden

Fiona Allpass, $\mathrm{PhD}$

Massey University, New Zealand

James Athanasou, $\mathrm{PhD}$

University of Sydney, Australia

Vanette McLennan, PhD

Griffith University, NSW, Australia

Scott Beveridge, PhD, LCPC, CRC, CDMS

The George Washington University, USA

Herbert C. Biggs, PhD

Queensland University of Technology, Australia

Dan Bilsker, PhD

University of British Columbia, Canada

Malachy Bishop, PhD, CRC

University of Kentucky, USA

Lesley Chenoweth, PhD

The University of Queensland, Australia

Chung-Yi Chiu, PhD

University of Illinois, Urbana-Champaign, USA

Chih Chin Chou, PhD, CRC

University of Arizona, USA

Julie Chronister, $\mathrm{PhD}$

San Francisco State University, USA

Judith Crockett, PhD

Charles Sturt University, Australia

Patricia Dorsett, PhD

Griffith University, Australia

Graeme Douglas, PhD

University of Birmingham, UK

Caroline Ellison, $\mathrm{PhD}$

Flinders University, Australia

Jennifer Harris, PhD

University of Dundee, Scotland, UK

Debra Homa, PhD

University of Wisconsin-Stout, USA

Ebonee T. Johnson, PhD

University of lowa, USA
Eun-Jeong Lee, PhD, CRC, LCPC

Illinois Institute of Technology, USA

Teresa Krupa, PhD

Queen's University, Canada

Frank Lane, PhD, CRC, LCPC

Illinois Institute of Technology, USA

Gloria Lee, PhD, CRC

Michigan State University, USA

Jen-Yi Li, PhD

Nanyang Technological University, National Institute of Education, Singapore

Mandy Matthewson, PhD

University of Tasmania, Australia

Vanette McLennan, PhD,

Griffith University, NSW, Australia

Michael Millington, PhD

The University of Sydney, Australia

David Peterson, PhD

California State University, USA

Doria Pilling, MA

City University London, UK

Bruce J. Reed, PhD

University of Texa Pan American, USA

Jon A. Sanford, M. Arch

Georgia Institute of Technology, USA

Jared C. Schultz, PhD, CRC

Utah State University, USA

Annabel Taylor, PhD

Central Queensland University, Australia

Kate van Heugten, $\mathrm{PhD}$

University of Canterbury, New Zealand

Ming Hung Wang, PhD

National Changhua University of Education,

Taiwan

Jun Yaeda, Rh.D.,

University of Tsukuba, Japan

Jacob Yui-Chung Chan, PhD

Ball State University, USA

Lisa Zheng, PhD, CRC

University of Maryland, USA

\section{Book Review Editors}

Tinashe M Dune

Western Sydney University

\section{Student Manuscripts}

Danielle Resiak, MRC, PhD Candidate University of Sydney

\section{Subscription Rates 2018}

This journal is published twice a year.

The institutional rates (excluding VAT) are:

$\begin{array}{lcc} & \begin{array}{c}\text { Print and } \\ \text { online } \\ \text { Australia }\end{array} & \begin{array}{c}\text { Online } \\ \text { only }\end{array} \\ \text { N America } & 260 \text { AUD } & 329 \text { AUD } \\ \text { UK and ROW } & \text { I73 GBP } & 242 \text { USD } \\ \text { I57 GBP }\end{array}$

EU subscribers (outside the UK) who are not registered for VAT should add VAT at their country's rate. VAT registered subscribers should provide their VAT registration number. Prices include delivery by air when appropriate. Japanese prices for institutions are available from Kinokuniya Company Ltd, P.O. Box 55, Chitose, Tokyo I56, Japan.

Orders and subscription enquiries should be addressed to:

Cambridge University Press, Journals Fulfillment Department, UPH, Shaftesbury Road, Cambridge CB2 8BS, UK

Orders from N America should be addressed to:

Cambridge University Press

Journals Fulfillment Department,

I Liberty Plaza, Floor 20, New York, NY 10006, USA

The Australian Journal of Rehabilitation Counselling and all other Cambridge Journals can be found at http://journals.cambridge.org/

Personal subscriptions to the Journal is covered by membership to the

Australian Society of Rehabilitation Counsellors.

For all inquiries please contact ASORC at www.asorc.org.au

\section{Advertising Rates}

The Australian Journal of Rehabilitation Counselling is a not-for-profit publication that is circulated to approximately 850 persons, including all members of the Australian Society of Rehabilitation Counsellors. The journal will accept advertising that may be of interest to its readers.

In the Americas, please contact

USAdSales@cambridge.org

For the Rest of World, please contact ad_sales@cambridge.org 


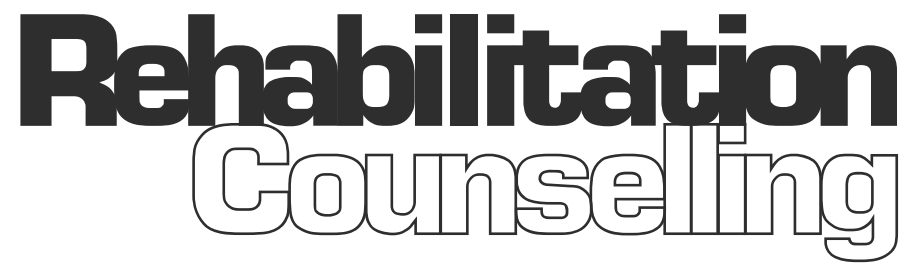

The Australian Journal of Rehabilitation Counselling (ASORC) is published twice a year and issued to all financial members of the Australian Society of Rehabilitation Counsellors.

Copyright in all articles rests with authors. A limited set of permanent copyright permission licences has been granted by authors to the publisher to allow publication in this journal. Rights in the reproduction and distribution of the published articles as visual facsimiles of this published edition by either mechanical or digital means is controlled by the publisher and any distributions by CAL for copying of an author's work therefore are due to the publisher and ASORC only.

All other rights in the words contained in this edition are controlled by the authors. Authors are therefore free to adapt and/or republish the words making up their own articles either online or in print.

\section{Published for}

the Australian Society of Rehabilitation Counsellors by Cambridge University Press, University Printing House, Shaftesbury Road Cambridge CB2 8BS United Kingdom journals.cambridge.org

\section{Articles}

Vocational Interests and Job Choices Following an Acquired Disability: Results and Implications of an Idiographic Study

James Athanasou

Work-Related Communication Barriers for

Individuals with Autism: A Pilot Qualitative Study

Michelle McKnight-Lizotte

Motivation and Readiness for Physical Activity and Exercise Behaviour among People with Chronic Musculoskeletal Pain: A Brief Report

Jessica M. Brooks, Kelly Costigan, Jia-Rung Wu, Xiangli Chen,

Kevin Bengtson, Fong Chan, Kanako Iwanaga and Chungyi Chiu

Challenges and Opportunities in International

Partnerships in Rehabilitation Counselling: An Exploratory Study

$\mathrm{Na}$ Lor, Wei-Mo Tu, David Rosenthal and Chen Wang 